Policy Research Working Paper 2433

External Interventions and the Duration of Civil Wars

Ibrahim A. Elbadawi

Nicholas Sambanis
Previous studies have argued

that longer civil wars have been caused by ethnically polarized societies, since rebel cohesion is easier and more lasting with polarization. This study shows that external interventions tend to reduce the cost of coordinating a rebellion for of fighting a rebellion), thereby lengthening the duration of civil wars even in societies that are not ethnically polarized.

The World Bank

Development Research Group

Public Economics

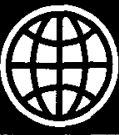

September 2000 


\section{Summary findings}

Elbadawi and Sambanis combine an empirical model of external intervention with a theoretical model of civil war duration. Their empirical model of intervention allows them to analyze civil war duration using "expected" rather than "actual" external intervention as an explanatory variable in the duration model.

Unlike previous studies, they find that external intervention is positively associated with the duration of civil war.

They distinguish partial third-party interventions that extend the length of war from multilateral "peace" operations, which have a mandate to restore peace without taking sides-and which typically take place at war's end, or at least when both sides have agreed to a cease-fire.

In a future paper the authors will examine whether partial third-party interventions-whatever their effect on a war's duration-increase the risk of war's recurrence. If that proves true, then even if interventions reduce the length of civil war they may do so at the cost of further destabilizing the political system and sowing the seeds of future rebellion.

This paper-a product of Public Economics, Development Research Group-is part of a larger effort in the group to study the economics of civil wars, crime, and violence. The study was funded by the Bank's Research Support Budget under the research project "The Economics of Political and Criminal Violence" (RPO 682-99). Copies of this paper are available free from the World Bank, 1818 H Street NW, Washington, DC 20433. Please contact Hedy Sladovich, room MC2-609, telephone 202-473-7698, fax 202-522-1154, email address hsladovich@worldbank.org. Policy Research Working Papers are also posted on the Web at www.worldbank.org/research/workingpapers. The authors may be contacted at ielbadawi@worldbank.org or nsambanis@worldbank.org. September 2000. (18 pages)

The Policy Research Working Paper Series disseminates the findings of work in progress to encourage the exchange of ideas about development issues. An objective of the series is to get the findings out quickly, even if the presentations are less than fully polished. The papers carry the names of the authors and should be cited accordingly. The findings, interpretations, and conclusions expressed in this paper are entirely those of the authors. They do not necessarily represent the view of the World Bank, its Executive Directors, or the countries they represent. 


\title{
External Interventions and the Duration of Civil Wars
}

\author{
Ibrahim A. Elbadawi
}

World Bank, Washington DC

Email: ielbadawi@worldbank.org

Nicholas Sambanis

World Bank, Washington DC

Email: nsambanis@worldbank.org

This paper was originally presented at the World Bank's Development Economic Research Group (DECRG) conference on "The Economics and Politics of Civil Conflicts", Princeton University, NJ, March 18-19, 2000. We would like to thank Patrick Regan for giving us his data on external intervention. 



\section{Introduction}

Studies on the economic and political determinants of civil wars have revealed that once a civil war has started, its termination depends critically on the balance of military capability between the government and the rebels. That balance is at least partially determined by the rebels' cohesion and their ability to resist government attempts to divide them into rival factions. A debate still is ongoing on the relative significance of the various determinants of that balance of capabilities between the government and rebel organizations. In this paper, we will focus on two such determinants which we consider very important: external interventions and the degree of ethnic fragmentation of the society; and we will consider the impact of these variables on the length of civil wars.

One influential argument in the literature is that the duration of civil wars is positively, though non-monotonically related to the level of ethnic fractionalization of the warring society (Collier, Hoeffler, and Soderbom, 1999). The implication is that polarized societies would generate longer civil wars because the cost of coordinating a rebellion for a long enough period could be prohibitively high in very diverse societies. The authors corroborate this argument in an empirical model of civil war duration using survival analysis of a large number of countries over the 1960-95 period. Importantly, they find that economic and political variables which other authors have identified as important for the initiation and overall incidence of civil war do not have an important impact on war duration. They therefore argue that war initiation and war duration are two distinct phenomena that deserve individual study.

Building on that important paper, Elbadawi (1999) elaborated a dynamic model of duration, in which he considered if external intervention --a variable not considered in Collier et al.-- has an effect in civil war duration. He argued that external intervention in favor of the rebels may have the effect of reducing the cost of sustaining a rebellion by a small ethnic group, which otherwise might not materialized or may be quickly crushed by the government. Therefore, in the presence of external intervention social polarization is not necessary as a cause of longer-lasting civil wars 9which was the principal finding of Collier et al.). Rather, external intervention could reduce the cost of coordinating a rebellion for a given level of ethnic fractionalization, thereby increasing the ease of mounting a rebellion and leading to longer-lasting wars. Because external intervention (in favor of the rebels) causes an upward shift in the hazard function of war for any given level of ethnic fractionalization, socially diverse and previously "safe" societies could become vulnerable to a higher incidence of longer civil wars.

In this paper, we take the Elbadawi (1999) paper a step forward, further developing the theoretical model and testing its propositions against a panel data-set which combines variables on war attributes and other socio-economic and political characteristics of 161 countries. We use preliminary data on external interventions 
constructed by Regan (2000) and we argue that external intervention is one of the major determinants of civil war determinants.

In section 2, we present our theoretical framework, linking war duration to external intervention. In section 3, we present some stylized facts and summary statistics associated with civil wars and external intervention in a global sample covering the 19601998 period. In section 4, we estimate a model of external intervention, where we predict the likelihood of intervention based on a set of determinants in countries which are at war. Unlike other studies, we argue that intervention is inherently an endogenous variable and therefore we do not include it as an exogenous regressor in our duration model, which we develop in section 5 . In section 5 , which contains our core empirical analysis, we therefore use expected, rather than current, external intervention as a key determinant of civil war duration. Our empirical analysis is based on ordered probit regressions. 'We conclude in section 6 with some suggestions for further study.

\section{Theory}

Civil war occurrence and duration may be modeled as the result of a forecast error on the part of the rebels or the state with reference to each other's military capability. ${ }^{2}$ Unlike international wars, which are usually short-lived, civil wars are prolonged. According to the argument above, this would mean that either the rebels, or the government, are over-optimistic about their relative military capability, leading to errors in judgement that prolong wars. The duration of the war is basically determined by the ability of the rebel movement to remain intact, sustain itself, and avoid military defeat.

What are some of the determinants of the rebels' ability to sustain their movement for long periods of time? Collier et al. argue that one important element is the degree of ethnic fragmentation in the society. They argue that very polarized societies produce longer wars because in such societies the rebels can more easily mobilize and sustain support among their ethnic group, which constitutes a sufficiently large segment of the country to provide the necessary support. The authors explain that during the course of the war, the government will try to divide the rebel movement and win over some factions to its side. In homogenous societies, rebel cohesion is likely to be more vulnerable to such government attempts, given the lack of strong socio-cultural or religious divide between the two camps. Moreover, for the case of diverse societies, maintaining the unity of a movement composed of diverse groups is likely to become

\footnotetext{
1 We have used ordered probit analysis as a first cut to the analysis of the determinants of civil war duration (see section 5). In the revised version of the paper, we plan to use survival analysis models.

2 See Collier, Hoeffler and Soderbom, 1999. A similar theoretical argument regarding international war is developed by Fearon 1995.
} 
harder over time. This leaves the case of polarized societies, for which rebellion can be sustained for a longer period. The authors also simulated the probability of duration and find that there is a high probability that a civil war will end during its first year. However, should the war continue beyond the first year, the probability of peace is radically lower for subsequent years. ${ }^{3}$

Though useful, the insight of Collier et al. does not take into considerations the dynamic and strategic interactions among the warring parties. By contrast, a theoretical framework proposed by Intriligator and Brito (1988 -- hereafter IB), accounts for these two features by analyzing the determinants of the rates of growth of rebel and government forces over time. ${ }^{4}$ In this paper, we will use IB theory as a basis for deriving, in the context of our two period framework, the probability that a civil war, once started, continues into the next period: $p_{r}(D>0)$.

Denoting the sizes of rebel and government forces at time t by $n_{r}(t)$ and $n_{g}(t)$, respectively, and the size of population living in territories under rebel control by $\operatorname{pop}_{r}(t), \mathrm{IB}$ state the following three differential equations describing the evolution of the three variables over time:

$$
\begin{aligned}
& \dot{n}_{r}=\left(\pi_{1} \text { pop }_{r}-\pi_{2} n_{g}\right) n_{r}, \pi_{1}, \pi_{2}>0 \\
& \dot{n}_{g}=\left(\pi_{3}-\pi_{4} n_{r}\right) n_{g}, \quad \pi_{3}, \pi_{4}>0 \\
& \dot{p o p}=\pi_{5} n_{r}-\pi_{6} n_{g}, \pi_{5}, \pi_{6}>0
\end{aligned}
$$

The first equation of motion suggests that the growth in rebel forces over time depends positively on the interaction of this force with the population under its control and negatively on its interaction with the government forces. The second equation suggests that the growth in the size of government army depends positively on its initial size and negatively on its interactions with rebel forces. Finally, the third equation assumes that the growth of the size of population living under rebel controls depends positively on the size of the rebel forces and negatively on the size of government forces.

\footnotetext{
${ }^{3}$ They explain this as a consequence of "the systematic over-optimism of rebels which would be predicted by random errors in estimates of the costs and benefits of rebellion. Many wars are mistakes, which do not produce rebel victory but rather military stalemate. Stalemates can be ended by negotiated settlements, but these encounter a time-consistency problem, with the government being unable credibly to commit to settlement terms. As a result, military stalemates persist" (Collier, Hoeffler, Soderbom, 1999, 17).

4 The representation of IB's theoretical framework is based on a review article by Sandler and Hartley (1995). See also Brito and Intriligator $(1989,1992)$.
} 
The steady state and the corresponding phase diagram, depicting behavior along and around the steady state, are described by the following six equations:

$$
\begin{aligned}
& \text { (4) } \quad \dot{n}_{r}=0 \text { if } \frac{n_{g}}{p o p_{r}}=\frac{\pi_{1}}{\pi_{2}}=\pi^{\prime} \text {, for } n_{r}>0 \\
& \text { (5) } \quad \dot{n}_{g}=0 \text { if } n_{r}=\frac{\pi_{3}}{\pi_{4}}=\pi^{\prime \prime} \text {, for } n_{g}>0 \\
& \text { (6) } \quad \dot{n}_{r}>0 \text { if } \frac{n_{g}}{p o p_{r}}>\pi^{\prime}, \\
& \text { (7) } \quad \dot{n}_{r}<0 \text { if } \frac{n_{g}}{p o p_{r}}<\pi^{\prime} \\
& \text { (8) } \quad \dot{n}_{g}>0 \text { if } n_{r}>\pi^{\prime \prime}, \\
& \text { (9) } \dot{n}_{g}<0 \text { if } n_{r}<\pi^{\prime \prime},
\end{aligned}
$$

where $\pi^{\prime}$ denotes the critical ratio of the size of government forces to the size of population living under rebel controls for there to be no change in the size of rebel forces, while $\pi^{n}$ indicates the critical size of the rebels forces consistent with a stationary size of the government army. Equations (4) -(9) give rise to a phase diagram in the $\left(n_{r}, n_{g}\right)$ space (see Sandler and Hartley, 1995: Figure 13.1), which we reproduce here for convenience. Both of phases II and IV are associated with short wars, where phase II (IV) suggests a quick government (rebels) victory, due to the rapid expansion of government (rebel) army while the rebels (government) forces shrink at the same rapid pace. On the other hand phases I and III are consistent with longer and stalemated wars, where in phase I (III) both forces shrink (expand) over time. We expand this framework in two important dimensions, recommended by Sandler and Hartley (1995) in their review article, by introducing uncertainty and by allowing the sizes of the phases (i.e. the probability events) to depend on behavioral determinants.

The four phases of the diagram can be expressed in terms of four events, which determine the probability of duration of war:

I: $\quad A_{1}\left(\pi_{(-)}^{\prime} \operatorname{pp}_{r}, \pi_{(-)}^{\prime \prime}\right)=\left\{n_{g}>\pi^{\prime} p_{p} p_{r}, n_{r}>\pi^{\prime \prime}\right\}$

II: $\quad A_{2}\left(\pi_{(-)}^{\prime} \operatorname{pop}_{r}, \pi_{(+)}^{\prime \prime}\right)=\left\{n_{g}>\pi^{\prime} p o p_{r}, n_{r}<\pi^{\prime \prime}\right\}$

III: $\left.\quad A_{3} \underset{(+)}{\left(\pi^{\prime} p_{(+)}\right.}, \underset{\pi^{\prime \prime}}{\pi^{\prime \prime}}\right)=\left\{n_{g}<\pi^{\prime} p_{p} p_{r}, n_{r}<\pi^{\prime \prime}\right\}$

IV: $\quad A_{4}\left(\pi_{(+)}^{\prime} p_{r}, \pi_{(-)}^{\prime \prime}\right)=\left\{n_{g}<\pi^{\prime} p o p_{r}, n_{r}>\pi^{\prime \prime}\right\}$ 
In the context of our two-period framework (where we characterize short wars as those that end in the same period and do not spill over into the following one): $p_{r}(D=0)=p_{r}\left(A_{2} \cup A_{4}\right)$ and $p_{r}(D>0)=p_{r}\left(A_{1} \cup A_{3}\right)$. Both probability statements could in turn be written as functionals of $\left(\pi^{\prime} p o p_{r}, \pi^{\prime \prime}\right)$, albeit for both functionals the net effect of these parameters could not be a priori signed. In the interest of analytical tractability, we will assume that the relevant event for determining the probability of stalemated civil war is $A_{3}$. Even though this assumption is subject to empirical testing, the prediction of this event that over time the sizes of the two armies in stalemated wars tend to grow (rather than shrink as predicted by $A_{1}$ ) appears to be more consistent with most actual civil war experiences. With this assumption, we write:

$$
p_{r}(D>0)=p_{r}\left[A_{3}\left(\pi_{(+)}^{\prime} p_{(+)}, \pi_{(+)}^{\prime \prime}\right)\right]
$$

\section{Figure 1: Phase Dynamics of Predator-Prey Guerrilla Warfare Model}

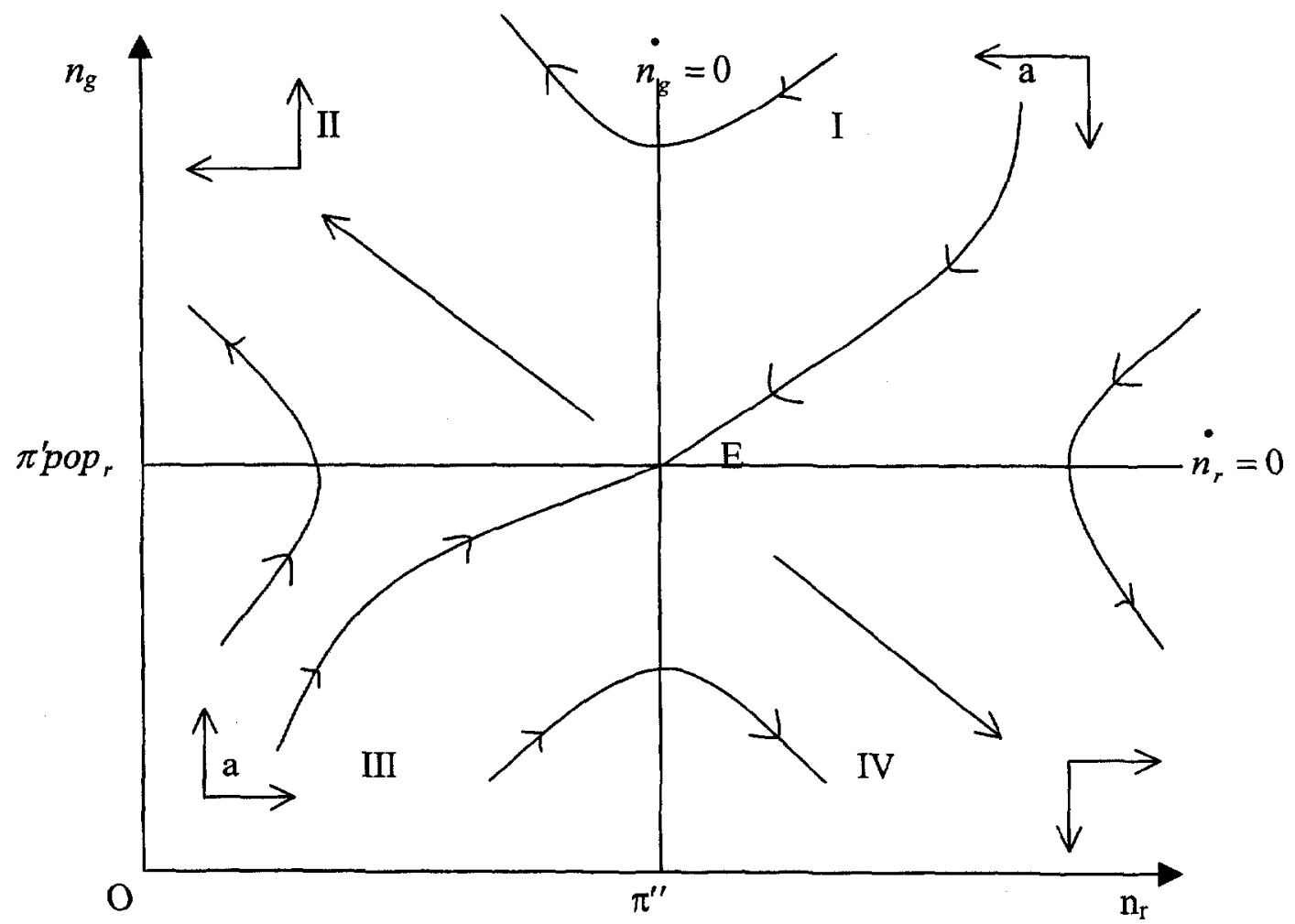

Source: Figure 13.1 of Sandler and Hartley (1995) 
The parameter $\left(\pi^{\prime} p o p_{r}\right)$ is influenced by factors that determine effectiveness of rebels' recruitment operations and the sympathy of certain segments of the population to the rebels' cause. In addition, it is also partially determined by factors that influence the capability of the rebel fighting force relative to that of the government forces (e.g., relative availability of resources to pay for soldiers' salaries and training or for purchases of arms). To fix the discussion we write the following specification for $\left(\pi^{\prime} p o p_{r}\right)$ :

$$
\begin{aligned}
& \pi^{\prime} \text { pop }{ }_{r}=f\left\{\text { elf }, \text { elf } * \text { ext }, \text { ext } * \delta\left(\text { rights }^{\oplus}\right), \delta\left(\text { rights }^{\oplus}\right), \text { elf }^{2}, x_{r}, \text { ext }\right\}, \\
& \begin{array}{llllll}
(+) & (?) & (+) & (-) & (-) & (+)
\end{array}
\end{aligned}
$$

where the latter set of factors are proxied by the ratio of the flow of natural resources controlled by rebels relative to real GNP $\left(x_{r}\right)$, where GNP is assumed to reflect the government's overall spending ability. The rest of the factors are assumed to influence the sympathy of the population with, and recruitment effectiveness of, the rebels. Ethnic fractionalization ( $e l f$ ) helps the rebels on both counts. However, as in the case of hazard of war theory, too much ethnic fractionalization could negatively affect both objectives: hence $\left(\right.$ elf $\left.^{2}\right)$ enters negatively. The direct effect of external intervention in favor of the rebels ( ext) is expected to raise rebel capability from relatively weaker initial levels and hence is expected to lead longer duration of conflicts. On the other hand, the interaction effect of external interventions in the presence of ethnic diversity $\left(e l f{ }^{*}\right.$ ext $)$ could not be a priori signed. ${ }^{5}$ However, we expect the net effect of external intervention to lead to longer duration. Finally, the variables $\delta\left(\right.$ rights $\left.^{\oplus}\right)$ and ext $^{*} \delta\left(\right.$ rights $\left.^{\oplus}\right)$ (where $\delta(. .$.$) is an indicator function) suggest that if government repression exceeds a certain$ threshold $\left(\right.$ rights ${ }^{\oplus}$ ) it tends to reduce duration of civil wars by raising the penalty for rebel sympathizers and thus hampers rebels' recruitment efforts, while external interventions (in favor of the rebels) would even up the effect of extreme autocracy by lowering the penalty threshold.

The remaining parameter $\left(\pi^{\prime \prime}\right)$ depends on factors that determine the initial stock of government forces in addition to the factors that influence capabilities of the government forces relative to those of the rebels. We specify the stock of government forces to be positively dependent on the total size of population in the country ( $p o p$ ) and the relative effectiveness of government forces to be a positive function of per capita income $(y)$ :

\footnotetext{
${ }^{5}$ However, the implication of this model for the effect of external intervention on the probability of duration of civil wars is not as straight forward as the case of the hazard of civil wars. The concept of intervention we adopt here is in terms of "net" intervention, which implies that external interventions in favor of the government should reduce duration. This, however, may run counter to some preliminary evidence, which suggests that interventions in favor of governments, rebels or both tend to lengthen intra state conflicts (Regan, 1996, 98, 2000). Again the model can accommodate a broader definition of interventions that allows interventions in favor of government to enter separately from those in favor of the rebels.
} 


$$
\pi^{\prime \prime}=g(p o p, y)
$$

Now equations (10)-(12) allow statement of the following expression for the probability of stalemated civil wars:

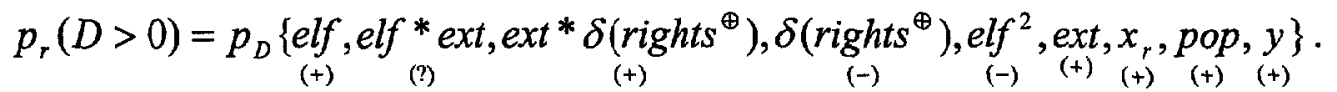

\section{Characteristics of Civil Wars and External Interventions}

Before attempting to undertake formal empirical analysis of the determinants of civil wars duration, we should briefly discuss some of the characteristics of these wars as well as the frequency and type of external interventions. The two panels of Figure 2 present the mean number of five-year periods during which a war took place in each of six regions of the world for the periods 1960-98 and 1980-98, respectively. They also present relative indices of the mean war duration, war-related deaths, democracy levels, and ethnic heterogeneity for these six regions.

Figure 2 points to an interesting geographical distribution of war. Africa has the highest incidence of civil war, especially if we combine the incidence of war in SubSaharan and North Africa. Perhaps more to the point, the incidence of war has increased in the last two decades in Africa, while it has fallen or remained stagnant in other regions (see the first column of Figure 2) ${ }^{6}$ However, wars in Africa are on average relatively short and they tend to be among the bloodiest (see columns 2 and 3 of Figure 2). They are therefore the most intense civil wars (in terms of casualties per unit of time). Only Asia has seen more war-related deaths than Africa in the last 40 years and this estimate need not include all civilian war-related deaths that were due to starvation, illness, and other disruptions caused indirectly by war in Africa.

Column 4 of Figure 2 also reveals a huge discrepancy in the democracy levels in Sub-Saharan and North Africa as compared to most other regions (Europe, North America, Latin America and the Caribbean, and Asia). Finally, column 5 of Figure 2 reveal that Africa (especially Sub-Saharan Africa) includes the most ethnically diverse countries than any other region in the world. These facts lend itself to speculation concerning a positive association between ethnic heterogeneity and political violence in Africa. However, few analysts have tried to explore that relationship in depth and even fewer have considered the possible role of Africa's relative lack of political rights and its

${ }^{6}$ We analyze the incidence of civil war in Africa in greater detail in Collier, Elbadawi, and Sambanis (2000b). 
overall lower level of economic development in exacerbating any conflict that ma $y$ result from its greater ethnic diversity.

\section{Conflicts and External Interventions}

As pointed out by Regan (2000, chapter 2), attaining a coherent and useful definition of foreign intervention is complicated by the need to understand the nature of the conflict that underlies the intervention, as well as by the need to account for the complex mix of factors that can shape an intervention strategy. That strategy can consist of either punishments or rewards (or both), and can range from incremental policies to massive onslaughts and may assist the government or support the rebellion. Our guide to overcome these complexities will be Regan (2000). We will define external intervention as a unilateral intervention by one (or more) third party government(s) in a civil war in the form of military, economic or mixed assistance in favor of either the government or the rebel movement involved in the civil war. This model of interventions is biased in favor of one of the two parties involved in the intra-state conflict. We distinguish between such partial interventions and what we call the "external agency" interventions, which are multilateral and essentially neutral, aiming at impartial resolution of conflicts (e.g., peacekeeping, peacemaking). We will argue in this paper that the two modes of intervention are very different in terms of their potential impacts on conflicts.

Figure 2 (1 of 2 Panels)

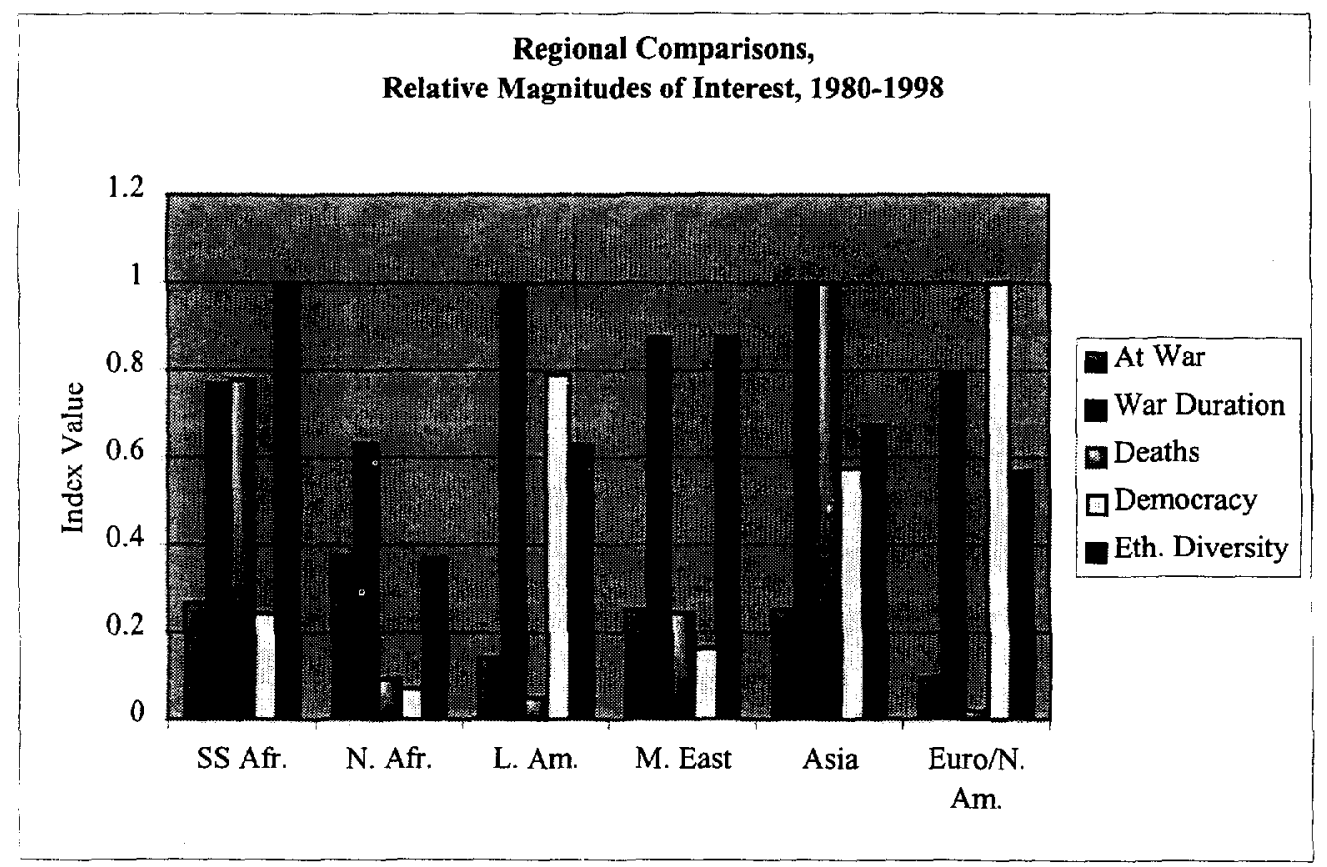


Figure 2 ( 2 of 2 panels)

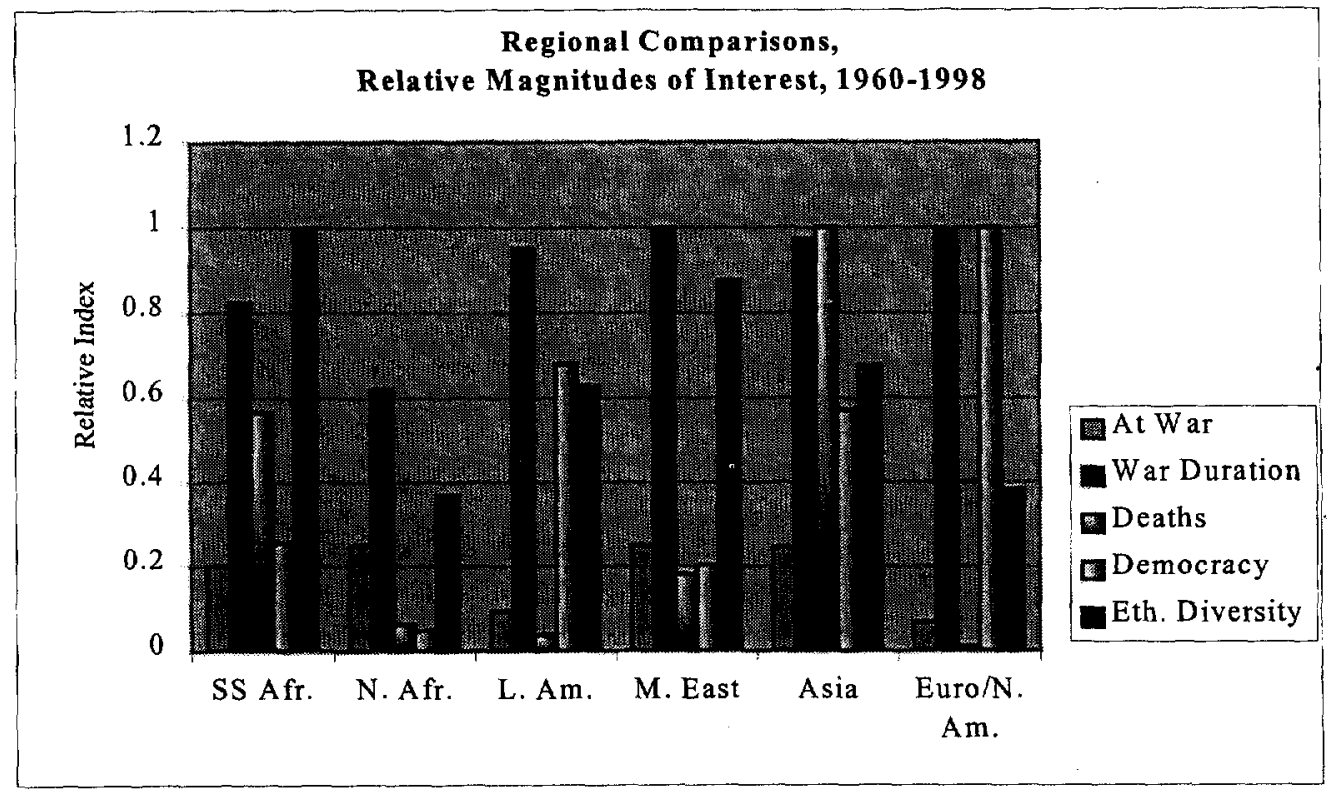

We use Regan's index of external intervention: a binary variable, indicating whether or not interventions have taken place in a given conflict. However, the index is rich enough to account for modes of interventions (military, economic, mixed) and target of interventions (government, opposition). In addition, this index disaggregates intervening third parties by country and by whether the intervention is unilateral or multilateral. ${ }^{7}$ Preliminary analysis of Regan's data suggests the following patterns (see Figure $3 \mathrm{~A}){ }^{8}$

\footnotetext{
${ }^{7}$ Some of the sources that Regan used to develop his data set are among the well known databases in this literature: Correlates of Civil War database (Singer and Small, 1994), the Annual Yearbook of the Stockholm International Peace Research Institute (SIPRI), Keesings Contemporary Archives (cited in Regan, 2000), The New York Times, and the Minorities at Risk Project. In addition he cites Herbert Tillema (1991, cited in Regan), Person and Baumann (1993, cited in Regan) and a host of case-specific historical documents as sources for the construction of the "external interventions" indexes.
}

${ }^{8}$ Figure $3 \mathrm{~A}$ is based on a new data set developed by Regan (2000), who constructs consistent indexes of indexes for intra-state conflicts as well as for external interventions going back as far as 1944. Unlike most well known definitions of conflicts that requires 1000 casualties for a conflict to qualify as a civil war (e.g., Singer and Small, 1994), Regan defines intra-state conflict as "armed, sustained combat between groups within state boundaries in which there are at least 200 fatalities." Regan argues that by lowering the threshold to less than a thousand this definition captures the seriousness of the conflict, yet the threshold is high enough to exclude events such as "bloodless" coups, riots and demonstrations. However, the version of the data set we have is, in fact, not significantly different from an updated data base based on Collier, Elbadawi and Sambanis (2000a, b). 
Out of 138 intra-state conflicts since 1944, 89 attracted external interventions by at least one external third party. Within the 89 cases, if repeated interventions were taken into account the total number of interventions amounts to 190 , of which 76 were accounted for by major powers. The countries with the dubious distinction of having the highest number of interventions are: USA (35), Former USSR/Russia (16), France (10), UK (9), China (6) and Cuba (5). Out of the 190 interventions, only 57 have led to an end in the fighting.

External interventions are associated with longer-lasting wars. A scatter diagram of war duration and external interventions during 1960-99 for all countries that have experienced civil wars reveals an upward-sloping relationship (Figure 3.B). Moreover, the mean duration of civil wars that were terminated and which had external interventions was nine years; while those wars that were terminated but did not have an intervention had a mean duration of only 1.5 years (Figure 3.C).

Figure 3.A: Intra-state Conflics and Interventions

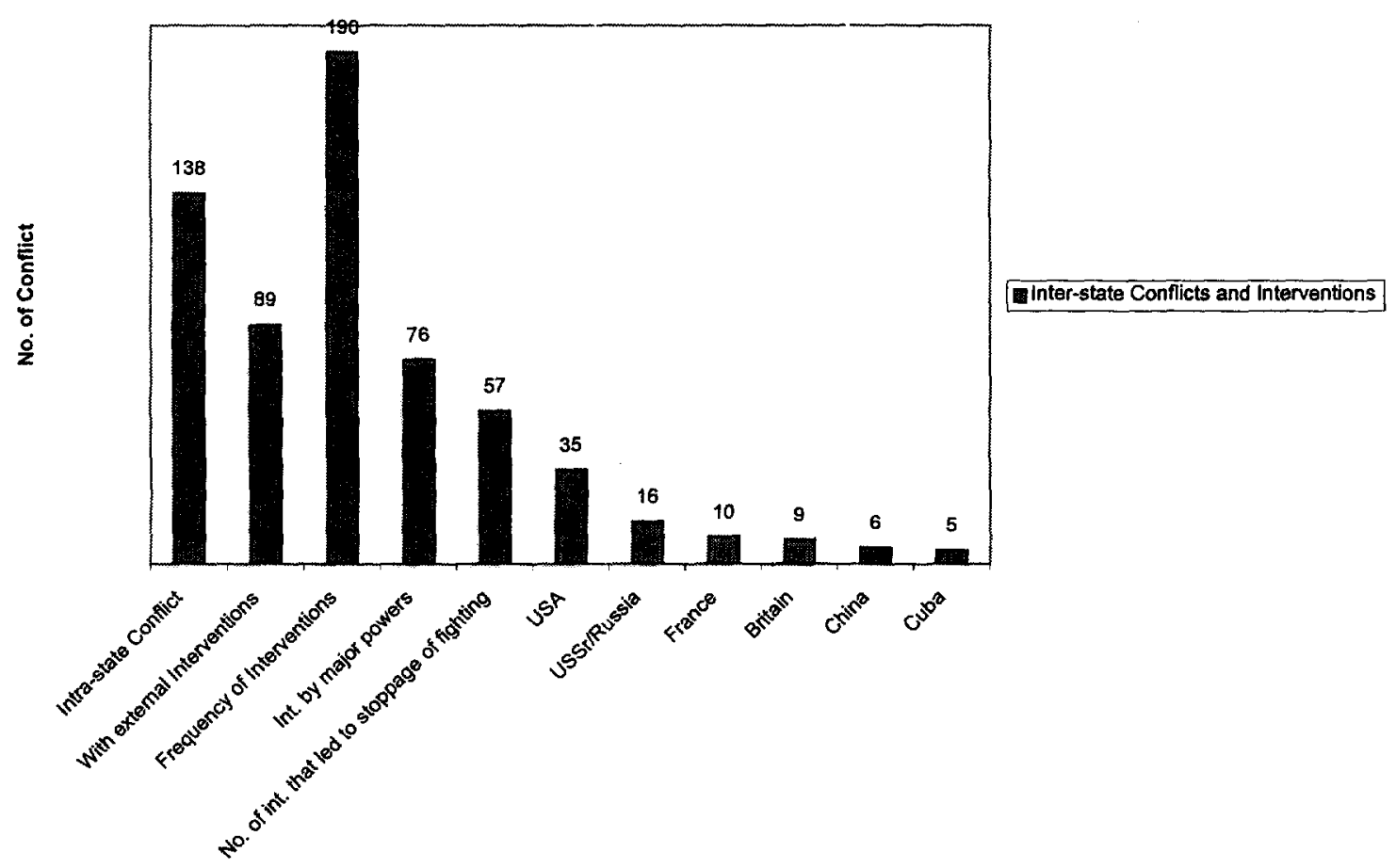


Figure 3.B

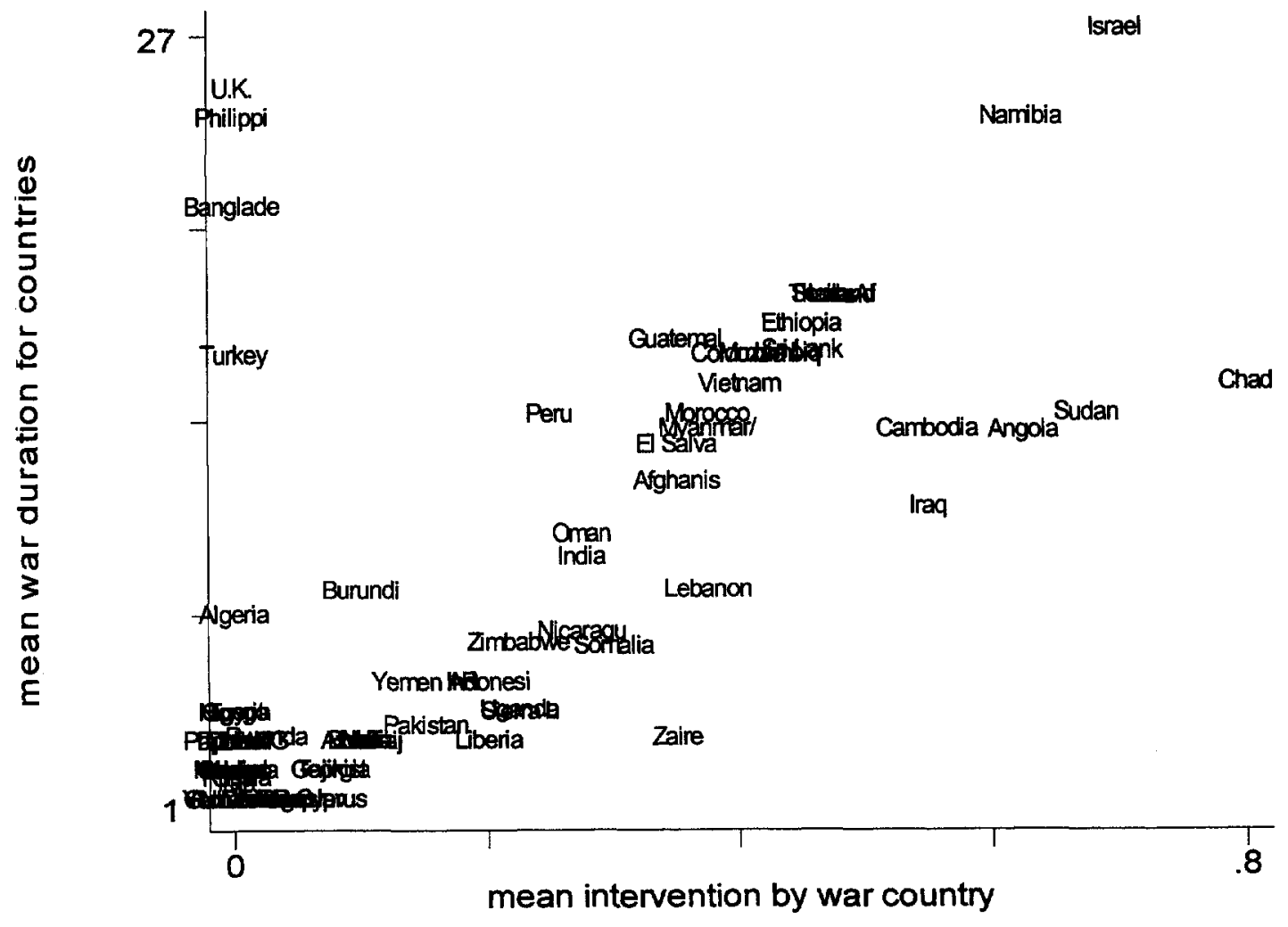

Figure 3.C: Interventions and Duration

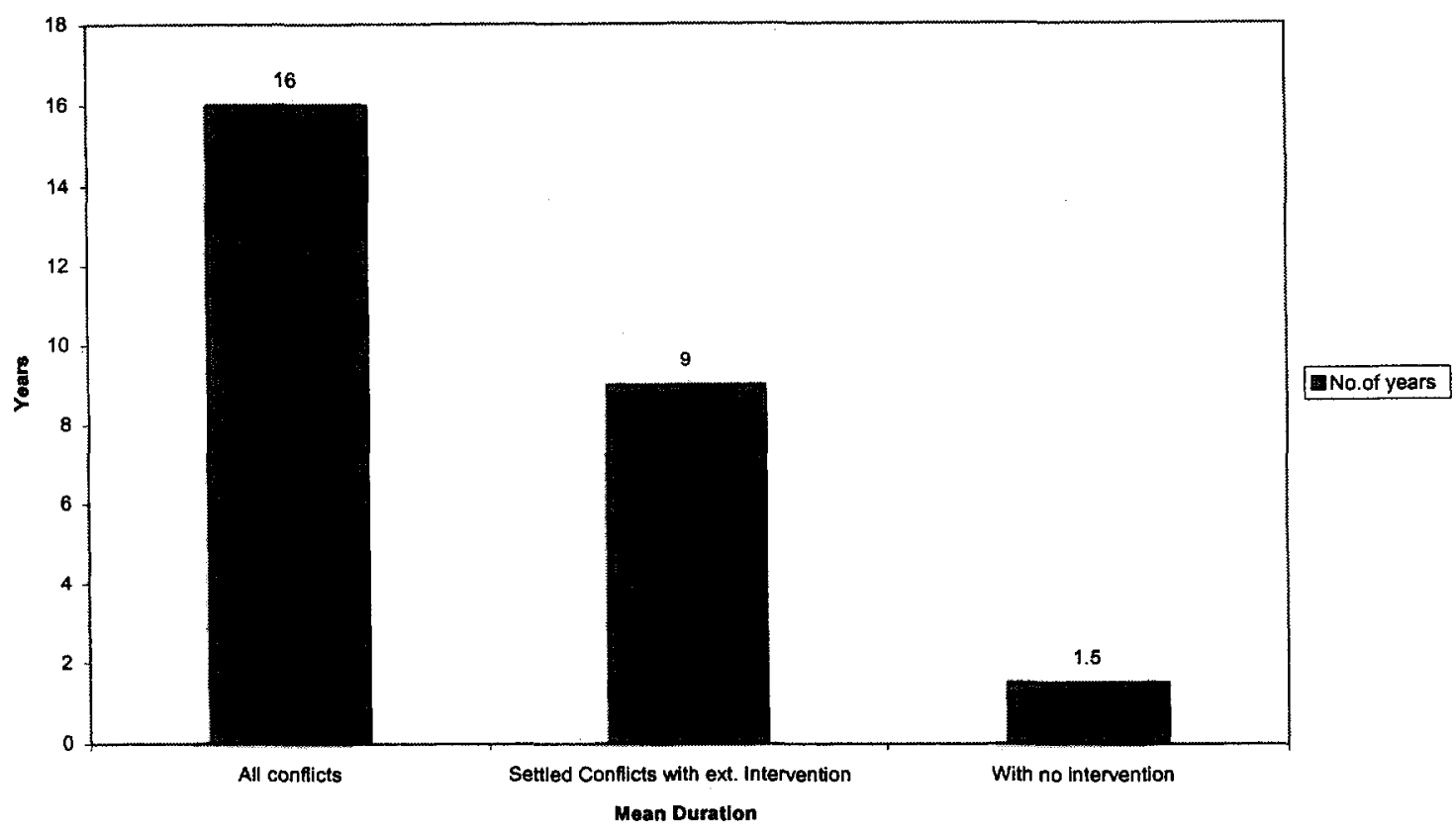




\section{Explaining External Interventions in Civil Wars}

The preliminary analysis in the previous section suggests that a positive association exists between external intervention and civil war duration. However, this evidence does not necessarily indicate a causal relationship. It may be the case that causality runs in the opposite direction and interventions may occur only in wars that are already long-lasting. To the extent that external intervention is indeed endogenous to war duration, expected rather than current levels of external interventions should be the appropriate explanatory variable in an empirical model of duration consistent with the theory of section 2 .

We therefore estimate a simple empirical model of external interventions and we assume that the probability of intervention is positively influenced by the length of war duration, as reflected by the date of initiation of the conflict (at_war). Also we assume that the costlier the war ( in terms of lives lost -- cost), the higher the probability of intervention. We also include a dummy for ethnic wars (ethwar) as well as indicators of the extent of ethnic fractionalization (elf, elf*elf), where a non-monotonic relationship is assumed, based on Collier et al. Our prior is that Ethwar (as well as elf) should be negatively associated with the probability of external intervention. This reflects the view that these are wars talking place in relatively marginal and non-strategic countries hence, ceteris paribus, these wars would attract little external intervention. We also assume that external intervention is less likely in countries with strong military capabilities (Imilp) or in a region with high standards of democracy (Regd) and in countries with very "deep" (i.e. high-scoring) democracies. ${ }^{9}$

To avoid endogeneity problems, all explanatory variables (except elf and Ethwar, which are time-invariant) are lagged. The results, based on a random effects probit model, are contained in Table 1. The evidence strongly corroborates our framework and suggest the following conclusions. First, external intervention is more likely in bloodier wars or when the government fighting the civil war is more democratic. Second, there is equally robust evidence suggesting that intervention is less likely to occur in ethnic wars, though the degree of ethnic fractionalization is not robustly associated with external intervention. Third, external intervention is also less likely in civil wars where regions are characterized by high levels of democracy or when the state involved in the civil war has a strong military.

\footnotetext{
9 To estimate this model and our model of war duration, we use data developed by Sambanis (2000). This is a cross-sectional time-series data-set of 161 countries between 1960-1999 with annual frequency. See Sambanis (2000) for a discussion of the variables in question.
} 
Table 1: Random Effects Probit Model of External Intervention

\begin{tabular}{|c|c|c|c|}
\hline $\begin{array}{l}\text { Dep. Var: Intervention } \\
\text { Regressors: }\end{array}$ & Coefficient & Standard Error & $P>|Z|$ \\
\hline $\begin{array}{l}\text { Deaths \& displacements (log) } \\
\text { (Cost) }\end{array}$ & $5.90 e-06$ & $1.75 e-06$ & 0.001 \\
\hline $\begin{array}{l}\text { Was it an ethnic war? } \\
\text { (ethwar) }\end{array}$ & -1.915 & .4325 & 0.000 \\
\hline $\begin{array}{l}\text { Military personnel (lagged once) } \\
\text { (Imilpll) }\end{array}$ & -.00357 & .00087 & 0.000 \\
\hline $\begin{array}{l}\text { Area affected by conflict } \\
\text { (Magarea) }\end{array}$ & -.2105 & .1486 & 0.157 \\
\hline $\begin{array}{l}\text { Lagged dummy for "deep" democracies } \\
\text { (Dpdeml1) }\end{array}$ & 2.151 & .5572 & 0.000 \\
\hline $\begin{array}{l}\text { Regional democracy average (lagged once) } \\
\text { (Regdll) }\end{array}$ & -.463 & .1042 & 0.000 \\
\hline $\begin{array}{l}\text { Dummy variable for region } \\
\text { (geo) }\end{array}$ & .4542 & .1282 & 0.000 \\
\hline Variable indicating war in previous period & 1.309 & .3898 & 0.001 \\
\hline Constant & -.045 & .925 & 0.961 \\
\hline $\begin{array}{l}\text { Insig } 2 \mathrm{u} \\
\text { LR test of rho=0 }\end{array}$ & $\begin{array}{l}2.293669 \\
\text { Chi2 }(1)=260.33\end{array}$ & $\begin{array}{l}.305391 \\
\text { Prob }>\operatorname{chi} 2=0.00\end{array}$ & 0.000 \\
\hline $\begin{array}{l}\text { Observations } \\
\text { Number of groups } \\
\text { Log-Likelihood } \\
\text { Wald chi2 (8) }\end{array}$ & \begin{tabular}{|c|}
508 \\
51 \\
-98.386 \\
45.78 \\
\end{tabular} & & \\
\hline
\end{tabular}

Using the results of Table 1 , we generate the predicted probability of external intervention, which we subsequently use as an explanatory variable in the empirical model of war duration which we analyze next.

\section{An Ordered Probit Model for Duration of Civil Wars}

Using equation 13 of the model of section 2 as a guide for our empirical analysis, we estimate an ordered probit model of the duration of civil wars (see results in Table 2 ). ${ }^{10}$ Our dependent variable is war duration categories -- an ordered variable coded in three intervals according to the quartiles of a continuous variable measuring war duration in months. Our regressors include a lagged index of autocracy (autoll); an index of ethnolinguistic diversity (elf; elf 2 ); the expectation of external intervention (phint); the $\log$ of population size, lagged once (poplagl); a variable coded 1 if the war was an ethnic

${ }^{10}$ We divided the data in four ordered duration categories, based on the quartile ranges of that variable. We included ongoing wars and computed their war duration up to the present, although a more correct approach would have been to drop ongoing wars and analyze only wars that have ended. We included ongoing wars because we eventually plan to use duration analysis to estimate our model. War categories are ordered from shortest duration to longest duration. 
war and 0 otherwise (ethwar); a control variable for the cold war (coldl1); and a number of interaction terms (see below). The estimation results corroborate the key predictions of the duration model of section 2 .

First, ethnic fractionalization (elf) is positively, but non-monotonically associated with war duration. The inverted U-shape relationship is fairly robust and highly significant, which confirms the main insight from Collier et al. that prolonged civil wars are usually associated with ethnically polarized societies. However, unlike these authors, who find only ethnic fractionalization to be robustly associated with duration, we find other significant relationships as well. We find that war duration is robustly associated with external intervention, war type, the war's cost in terms of casualties and displacements, and with the level of political oppression in the country.

Table 2: Ordered Probit Regressions On Civil War Duration

(Robust standard errors reported in parentheses)

\begin{tabular}{|c|c|c|c|}
\hline $\begin{array}{l}\text { Dep. Var.: War Duration Category } \\
\text { Regressors: }\end{array}$ & Regression $2 a$ & Regression $2 b$ & Regression $2 c$ \\
\hline $\begin{array}{l}\text { Autocracy index (lagged once) } \\
\text { (autol1) }\end{array}$ & $\begin{array}{l}-.1732 \\
(.112)\end{array}$ & $\begin{array}{l}-.224^{\star} \\
(.122)\end{array}$ & $\begin{array}{l}-.229^{*} \\
(.123)\end{array}$ \\
\hline $\begin{array}{l}\text { Ethnolinguistic diversity index } \\
(E \perp f)\end{array}$ & $\begin{array}{l}.121^{\star} \\
(.063)\end{array}$ & $\begin{array}{l}.189 * \star \\
(.054)\end{array}$ & $\begin{array}{l}.188 * \star \\
(.055)\end{array}$ \\
\hline $\begin{array}{l}\text { ELF index squared } \\
(E \perp f 2)\end{array}$ & $\begin{array}{l}-.0012 * * \\
(.0006)\end{array}$ & $\begin{array}{c}-.002 \star * \\
(.0005)\end{array}$ & $\begin{array}{l}-.0018 * * \\
(.0005)\end{array}$ \\
\hline $\begin{array}{l}\text { Expected external intervention } \\
\text { (Ph3int) }\end{array}$ & $\begin{array}{l}.532 * \\
(.3106)\end{array}$ & $\begin{array}{l}1.38 * * \\
(.579)\end{array}$ & $\begin{array}{l}1.39 * * \\
(.582)\end{array}$ \\
\hline $\begin{array}{l}\text { Log of population size lagged once } \\
\text { (logpop 11) }\end{array}$ & $\begin{array}{l}.332 \\
(.388)\end{array}$ & $\begin{array}{l}.333 \\
(.374)\end{array}$ & $\begin{array}{l}.339 \\
(.372)\end{array}$ \\
\hline $\begin{array}{l}\text { Dummy variable for ethnic wars } \\
\text { (Ethwar) }\end{array}$ & $\begin{array}{l}2.26 * * \\
(.596)\end{array}$ & $\begin{array}{l}2.11^{\star \star} \\
(.592)\end{array}$ & $\begin{array}{l}2.09 * * \\
(.597)\end{array}$ \\
\hline $\begin{array}{l}\text { Interaction term: Phint } * \text { elf } \\
\text { (Phielf) }\end{array}$ & $\begin{array}{l}-.0052 \\
(.0057)\end{array}$ & $\begin{array}{l}-.054^{\star \star} \\
(.026)\end{array}$ & $\begin{array}{l}-.055^{*} * \\
(.026)\end{array}$ \\
\hline $\begin{array}{l}\text { Interaction term: Phint * elf2 } \\
\text { (Phielf } 2)\end{array}$ & -- & $\begin{array}{l}.0005^{\star} \\
(.0003)\end{array}$ & $\begin{array}{l}.0005^{*} \\
(.0003)\end{array}$ \\
\hline $\begin{array}{l}\text { Interaction term: Phint }{ }^{*} \text { cost } \\
\text { (phico) }\end{array}$ & $\begin{array}{l}-2.64 e-07 \star \\
(1.57 e-07)\end{array}$ & $\cdots$ & --- \\
\hline $\begin{array}{l}\text { Interaction term: Phint } * \text { dall } \\
\text { (phidal1) }\end{array}$ & $\begin{array}{l}.452 * \\
(.246)\end{array}$ & $\begin{array}{l}.522 * \star \\
(.231)\end{array}$ & $\begin{array}{l}.530 * * \\
(.231)\end{array}$ \\
\hline $\begin{array}{l}\text { Cold War (lagged once) } \\
\text { (cold11) }\end{array}$ & $\begin{array}{l}-.265 \\
(.296)\end{array}$ & $\begin{array}{l}-.204 \\
(.323)\end{array}$ & -- \\
\hline Observations: & 438 & 438 & 438 \\
\hline $\begin{array}{l}\text { Log likelihood: } \\
\text { Pseudo R2: } \\
\text { Ancillary Parameters: }\end{array}$ & $\begin{array}{c}-507.08839 \\
0.1120\end{array}$ & $\begin{array}{c}-498.58128 \\
0.1269\end{array}$ & $\begin{array}{c}-498.9541 \\
0.1262\end{array}$ \\
\hline - cut1 & $\begin{array}{l}7.62 \\
(6.1)\end{array}$ & $\begin{array}{l}8.86 \\
(6.3)\end{array}$ & $\begin{array}{l}9.09 \\
(6.2)\end{array}$ \\
\hline _cut2 & $\begin{array}{l}9.31 \\
(6.16)\end{array}$ & $\begin{array}{l}10.61 \\
(6.37)\end{array}$ & $\begin{array}{l}10.83 \\
(6.26)\end{array}$ \\
\hline _cut 3 & $\begin{array}{l}11.62 \\
(6.38) \\
\end{array}$ & $\begin{array}{l}12.94 \\
(6.51) \\
\end{array}$ & $\begin{array}{l}13.15 \\
(6.39)\end{array}$ \\
\hline
\end{tabular}

** Denotes significance at .05 level; * denotes significance at .1 level 
Specifically, we find first, that ethnic wars are generally longer than other types of civil war, since the coefficient of ethwar is robustly significant and positive. This finding is in agreement with much of the political science literature which tends to argue that ethnic wars are harder to resolve (e.g., Kaufmann 1996).

Second, we find expected external intervention (Phint) to have a positive and highly significant association with war duration. The estimated coefficient is highly significant and stable (ranging from 1.33 to 1.38 in the three variations of the model specification we present in Table 2). This level of impact would more than outweigh the interaction effects of intervention with other variables (see below) and the net effect of external intervention would be to increase war duration.

Third, using interaction terms, we also explore the effects of intervention in ethnically diverse societies using interaction terms (Phielf, Phielf2) as well as in wars with high casualties, interacting the expected intervention regressor with the log of deaths and displacements (Phico). Only (Phielf) is found to be robustly significant, which has a negative coefficient ranging from -.040 to -.054 .

Fourth, the direct effect of extreme autocracy is negative and significant, suggesting that more autocratic regimes can more easily quell rebellions. At the same time the lagged interaction term between external intervention and extreme autocracies (Phidall) is positive and significant with an estimated coefficient ranging from .52 to .6). Thus, interventions in wars against extremely autocratic governments have the effect of lengthening the war's duration.

\section{Implications for the Role of External Interventions and Extreme Autocracy? ${ }^{11}$}

For a given degree of ethnic fractionalization, external intervention will shift and cause an upward shift in the inverted U-shaped hazard function and hence will increase the duration of conflict for any given level of elf. If we also account for the negative effect due to the interaction term (Phielf), the hazard function should shift both upwards as well as to the left. ${ }^{12}$ This result corroborates one of the most important insights of our model in that with external intervention, longer civil wars can be sustained even in diverse (i.e. not polarized or ethnically-dominated) societies. This finding would relax the constraint that it takes ethnic polarization to produce long duration of conflict (Collier et al. 1999).

\footnotetext{
11 In this section, we discuss relative effects of the different variables on war duration. This is an incomplete discussion that we intend to expand in the final draft of the paper.

12 In a subsequent version, we will conduct simulations to empirically derive these effects.
} 
Finally, autocracy (autoll) is associated with shorter duration of conflicts while external intervention under in autocratic regimes (Phidall) tends to be associated with longer-lasting wars. External intervention therefore seems to generate a counter balancing effect that possibly reduces an autocracy's ability to quell a rebellion, leading to longer wars. The net effect is an empirical question, depending on the relative orders of magnitude of the two opposing effects described here.

\section{Conclusion}

This paper combines an empirical model of external intervention with a theoretical model of civil war duration. In doing so, it treats external intervention as an endogenous variable and, contrary to previous studies, finds that external intervention is positively associated with war duration. This finding contradicts previous studies which typically argue that interventions may reduce the duration of the war (see, e.g., Betts 1994).

The results presented in this paper are preliminary and need further testing and elaboration. In future revisions of this paper, we intend to develop the theory of intervention by integrating various theoretical insights from the qualitative and case-study literature. We also intend to use duration analysis methods and build our data-set so that we test the nuances of our model with greater accuracy. Specifically, we want to acquire data that allows us to discriminate between the type and target of the intervention and which provides us information on the timing of each of multiple interventions that may have taken place in a single war. In the current draft of the paper, we did not have access to such data and were therefore unable to develop our analysis further. We believe, however, that the preliminary findings that we have presented in this draft, along with our theoretical framework and the endogenization of the intervention variable are both useful and encouraging and that they point to the need to question the theoretical and empirical foundation of the argument that external partial intervention limits civil war duration, or that ethnic polarization is the only significant determinant of long war duration.

Further research could usefully analyze and contrast the impact on war duration of partial as opposed to impartial, multilateral interventions. Multilateral "peace" operations should be distinguished from partial interventions by their mandate to restore peace without taking sides. Most of these operations tend to take place after wars end -- or at least when a cease-fire has been agreed-- so it may not be feasible to conduct a fullfledged comparison to partial intervention with respect to their impact on war duration. Such a comparison would be possible by concentrating on Chapter VII UN operations -peace enforcement-- which typically do take sides according to the mandate assigned to them by the Security Council. Finally, in a revised version of this paper, we plan to conduct a study of war recurrence, as an additional section to this paper, where we will 
use war duration as an endogenous explanatory variable and will examine if partial third party interventions --regardless of their effect on war duration--have the effect of increasing the risk of war recurrence. If that is the case, then even if interventions do reduce the length of civil wars, then they may be doing so at the cost of destabilizing the political system further and sowing the seeds of future rebellion.

\section{References}

Betts, Richard. “The Delusions of Impartial Intervention," Foreign Affairs (1994), 73: 6.

Brito, D. and M. Intriligator. 1989. "An Economic Model of Guerrilla Warfare," International Transaction, 15(3), 319-29.

Brito, D. and M. Intriligator. 1992. "Narco-traffic and Guerrilla Warfare: A New Symbiosis," Defense Economics, 3(4), 263-74.

Collier, P. 1998. 'The Economics of Civil Wars' Development Research Group, The World Bank, mimeo.

Collier, Paul and Anke Hoeffler. 1999. "Justice-Seeking and Loot-Seeking in Civil War," (February) Working Paper, World Bank.

Collier, Paul and Anke Hoeffler, "On economic causes of civil war," Oxford Economic Papers 50 (1998), 563-573.

Collier, Paul, Anke Hoeffler and Mans Soberdom (1999), "On the Duration of

Civil War" World Bank, unpublished mimeo.

Collier, Paul, Ibrahim Elbadawi, and Nicholas Sambanis (2000a) "How Much War Will We See? Estimating the Likelihood and Amount of War in 161 Countries, 19601998." Unpublished mimeo, The World Bank (January).

Collier, Paul, Ibrahim Elbadawi, and Nicholas Sambanis (2000b). "Why Are There So Many Civil Wars In Africa?" manuscript, World bank (February 2000).

Elbadawi, Ibrahim (1999), "Civil Wars and Poverty: The Role of External Interventions, Political Rights and Economic Growth," presented at the World Bank's Conference on "Civil Conflicts, Crime and Violence," Washington, DC, Feb. 2223.

Intriligator, M. and D. Brito. 1988. "A Predator-Prey Model of Guerrilla Warfare," Syntheses, 76(2), 235-49.

Kaufmann, Chaim (1996), "Possible and Impossible Solutions to Ethnic Conflicts," International Security. Vol. 20, no. 4, pp. 136-175.

Regan, P. 2000. Civil Wars and Foreign Powers: Outside Interventions and Intrastate Conflicts. Ann Arbor. University of Michigan Press: chapter 2.

Regan, Patrick. 1998. "Choosing to Intervene," Journal of Politics. 
Regan, P. 1996. “Conditions for Successful Third Party Interventions," Journal of Conflict Resolution.

Sambanis, Nicholas. 2000. "Ethnic War: A Theoretical and Empirical Inquiry into its Causes." Manuscript: World Bank DECRG (February 2000).

Sandler, T. and K. Hartley. 1995. "Nonconventional Conflict: revolutions, guerrilla

warfare, and terrorism", in T. Sandler and K. Hartley (eds), The Economics of Defense, Cambridge University Press.

Singer, J.D. and M. Small. 1994. Correlates of War Project: International and Civil War Data, 1816-1992. Inter-University Consortium for Political and Social Research, Ann Arbor, Michigan. 


\section{Policy Research Working Paper Series}

\begin{tabular}{|c|c|c|c|c|}
\hline & Title & Author & Date & $\begin{array}{l}\text { Contact } \\
\text { for paper }\end{array}$ \\
\hline WPS2416 & $\begin{array}{l}\text { The Swiss Multi-Pillar Pension } \\
\text { System: Triumph of Common Sense? }\end{array}$ & $\begin{array}{l}\text { Monika Queisser } \\
\text { Dimitri Vittas }\end{array}$ & August 2000 & $\begin{array}{l}\text { A. Yaptenco } \\
31823\end{array}$ \\
\hline WPS2417 & The Indirect Approach & David Ellerman & August 2000 & $\begin{array}{l}\text { B. Mekuria } \\
82756\end{array}$ \\
\hline WPS2418 & $\begin{array}{l}\text { Polarization, Politics, and Property } \\
\text { Rights: Links between Inequality } \\
\text { and Growth }\end{array}$ & $\begin{array}{l}\text { Philip Keefer } \\
\text { Stephen Knack }\end{array}$ & August 2000 & $\begin{array}{l}\text { P. Sintim-Aboagye } \\
37644\end{array}$ \\
\hline WPS2419 & $\begin{array}{l}\text { The Savings Collapse during the } \\
\text { Transition in Eastern Europe }\end{array}$ & $\begin{array}{l}\text { Cevdet Denizer } \\
\text { Holger C. Wolf }\end{array}$ & August 2000 & $\begin{array}{l}\text { I. Partola } \\
35759\end{array}$ \\
\hline WPS2420 & $\begin{array}{l}\text { Public versus Private Ownership: } \\
\text { The Current State of the Debate }\end{array}$ & $\begin{array}{l}\text { Mary Shirley } \\
\text { Patrick Walsh }\end{array}$ & August 2000 & $\begin{array}{l}\text { Z. Kranzer } \\
38526\end{array}$ \\
\hline WPS2421 & $\begin{array}{l}\text { Contractual Savings or Stock Market } \\
\text { Development-Which Leads? }\end{array}$ & $\begin{array}{l}\text { Mario Catalan } \\
\text { Gregorio Impavido } \\
\text { Alberto R. Musalem }\end{array}$ & August 2000 & $\begin{array}{l}\text { P. Braxton } \\
32720\end{array}$ \\
\hline WPS2422 & $\begin{array}{l}\text { Private Provision of a Public Good: } \\
\text { Social Capital and Solid Waste } \\
\text { Management in Dhaka, Bangladesh }\end{array}$ & $\begin{array}{l}\text { Sheoli Pargal } \\
\text { Daniel Gilligan } \\
\text { Mainul Huq }\end{array}$ & August 2000 & $\begin{array}{l}\text { S. Pargal } \\
81951\end{array}$ \\
\hline WPS2423 & $\begin{array}{l}\text { Financial Structure and Economic } \\
\text { Development: Firm, Industry, and } \\
\text { Country Evidence }\end{array}$ & $\begin{array}{l}\text { Thorsten Beck } \\
\text { Asl1 Demirgüç-Kunt } \\
\text { Ross Levine } \\
\text { Vojislav Maksimovic }\end{array}$ & August 2000 & $\begin{array}{l}\text { K. Labrie } \\
31001\end{array}$ \\
\hline WPS2424 & $\begin{array}{l}\text { Global Transmission of Interest } \\
\text { Rates: Monetary Independence and } \\
\text { the Currency Regime }\end{array}$ & $\begin{array}{l}\text { Jeffrey Frankel } \\
\text { Sergio Schmukler } \\
\text { Luis Servén }\end{array}$ & August 2000 & $\begin{array}{l}\text { E. Khine } \\
37471\end{array}$ \\
\hline WPS2425 & $\begin{array}{l}\text { Are Returns to Investment Lower for } \\
\text { the Poor? Human and Physical } \\
\text { Capital Interactions in Rural Vietnam }\end{array}$ & Dominique van de Walle & August 2000 & $\begin{array}{l}\text { H. Sladovich } \\
37698\end{array}$ \\
\hline WPS2426 & $\begin{array}{l}\text { Commodity Price Uncertainty in } \\
\text { Developing Countries }\end{array}$ & Jan Dehn & August 2000 & $\begin{array}{l}\text { P. Varangis } \\
33852\end{array}$ \\
\hline WPS2427 & $\begin{array}{l}\text { Public Officials and Their Institutional } \\
\text { Environment: An Analytical Model for } \\
\text { Assessing the Impact of Institutional } \\
\text { Change on Public Sector Performance }\end{array}$ & $\begin{array}{l}\text { Nick Manning } \\
\text { Ranjana Mukherjee } \\
\text { Omer Gokcekus }\end{array}$ & August 2000 & $\begin{array}{l}\text { C. Nolan } \\
30030\end{array}$ \\
\hline WPS2428 & $\begin{array}{l}\text { The Role of Foreign Investors in Debt } \\
\text { Market Development: Conceptual }\end{array}$ & Jeong Yeon Lee & August 2000 & $\begin{array}{l}\text { A. Yaptenco } \\
38526\end{array}$ \\
\hline
\end{tabular}




\section{Policy Research Working Paper Series}

\begin{tabular}{|c|c|c|c|c|}
\hline & Title & Author & Date & $\begin{array}{l}\text { Contact } \\
\text { for paper }\end{array}$ \\
\hline WPS2429 & $\begin{array}{l}\text { Corruption, Composition of Capital } \\
\text { Flows, and Currency Crises }\end{array}$ & Stang-Jin Wei & August 2000 & $\begin{array}{l}\text { H. Sladovich } \\
37698\end{array}$ \\
\hline WPS2430 & $\begin{array}{l}\text { Financial Structure and Bank } \\
\text { Profitability }\end{array}$ & $\begin{array}{l}\text { Asli Demirgüç-Kunt } \\
\text { Harry Huizinga }\end{array}$ & August 2000 & $\begin{array}{l}\text { K. Labrie } \\
31001\end{array}$ \\
\hline WPS2431 & $\begin{array}{l}\text { Inside the Crisis: An Empirical } \\
\text { Analysis of Banking Systems in } \\
\text { Distress }\end{array}$ & $\begin{array}{l}\text { As i Demirgüç-Kunt } \\
\text { Enrica Detragiache } \\
\text { Poonam Gupta }\end{array}$ & August 2000 & $\begin{array}{l}\text { K. Labrie } \\
31001\end{array}$ \\
\hline WPS2432 & $\begin{array}{l}\text { Funding Growth in Bank-Based and } \\
\text { Market-Based Financial Systems: } \\
\text { Evidence from Firm-Level Data }\end{array}$ & $\begin{array}{l}\text { Asli Demirgüç-Kunt } \\
\text { Vojislav Maksimovic }\end{array}$ & August 2000 & $\begin{array}{l}\text { K. Labrie } \\
31001\end{array}$ \\
\hline
\end{tabular}

